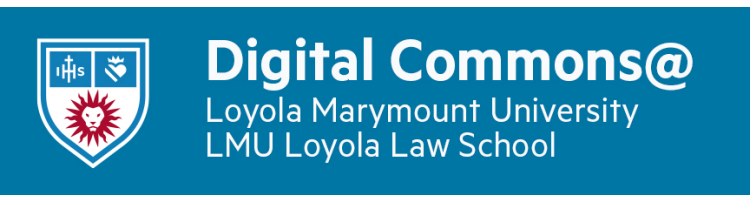

Journal of Catholic Education

Volume 16 | Issue 1

Article 7

9-17-2012

\title{
School Turnaround: Cristo Rey Boston High School Case Study
}

Jeffrey Thielman

Follow this and additional works at: https://digitalcommons.Imu.edu/ce

\section{Recommended Citation}

Thielman, J. (2012). School Turnaround: Cristo Rey Boston High School Case Study. Journal of Catholic Education, 16 (1). http://dx.doi.org/10.15365/joce.1601072013

This Article is brought to you for free with open access by the School of Education at Digital Commons at Loyola Marymount University and Loyola Law School. It has been accepted for publication in Journal of Catholic Education by the journal's editorial board and has been published on the web by an authorized administrator of Digital Commons at Loyola Marymount University and Loyola Law School. For more information about Digital Commons, please contact digitalcommons@lmu.edu. To contact the editorial board of Journal of Catholic Education, please email JCE@nd.edu. 


\section{School Turnaround: Cristo Rey Boston High School Case Study}

Jeff Thielman

Cristo Rey Boston High School, Massachusetts

The mandates of the federal No Child Left Behind Law, including the threat of closing a school for underperformance, have led to multiple public school turnaround attempts. Because turnaround is a relatively new area of focus in education, there is limited research on what does and does not work, and even the definition of turnaround is a work in progress. The research that is available is almost exclusively from the public school sector. This article gives some history and context for school turnarounds currently taking place in the United States and describes the turnaround of a Catholic, inner-city high school in the Archdiocese of Boston. The school, Cristo Rey Boston High School-formerly North Cambridge Catholic High School-has a history spanning nearly roo years. Unlike a public school, North Cambridge Catholic High School was not subject to closure or takeover for consistently poor student performance on standardized tests. Instead, the principal and his faculty were driven by their own desire to improve the quality of education they were offering their students.

$\mathrm{C}$ risto Rey Boston High School (formerly North Cambridge Catholic High School) is an example of a self-directed school turnaround in which a principal and a core group of dedicated teachers had the autonomy and flexibility needed to strengthen the curriculum, change the school schedule, improve instructional practices, and address staffing issues. Their efforts dramatically improved student outcomes and created a new culture for teaching and learning. In an era of federally mandated turnaround strategies, the changes initiated at Cristo Rey Boston High School are indicative of what can be accomplished when a dedicated leader and a core group of inspired teachers are motivated and empowered to provide a better education to the students they are teaching.

Although most schools aspire to ongoing improvement, school turnarounds as we think of them today are most often externally driven (Calkins, Guenther, Belfiore, \& Lash, 2007; Pappano, 2010). Under the federal No Child Left Behind law, state departments of education review all public schools annually to determine if they are making progress toward the goal of all students reaching 
grade-level academic proficiency (Massachusetts Department of Elementary and Secondary Education, 20Ir; U.S. Department of Education, 2006). Failure to ensure growth in student learning over consecutive years results in a series of increasingly prescriptive interventions that include the development and implementation of a school improvement plan, placement in a specific restructuring category, or closure (U.S. Department of Education, 2006).

Catholic schools do not operate under the mandates and scrutiny of federal education laws. Absent rigorous accountability structures that ensure data transparency and systemic supports, private and Catholic schools must address change internally. The lesson from this case study of a Catholic high school is that an internal effort to improve the quality of education, even if the impetus for change is an external imperative to save the school, is necessary for a successful turnaround.

\section{School Turnaround: Impetus and Definition}

School performance declines for a variety of reasons. In his study of schools that were adequate or good performers and subsequently became underperformers, Duke (2008) identified II symptoms of decline. These included: I.) the absence of a method to identify and assist learning problems and deficits in students not on Individual Education Plans (IEPs); 2.) the poor monitoring of student progress; 3.) an inflexible daily school schedule; 4.) classroom instruction not aligned with state standards; 5.) staff development unrelated to core academic issues; 6.) a lack of "clear academic focus;" 7.) poor leadership; 8.) a tendency to make hires too quickly; 9.) increased class size; ro.) a high number of untrained people working with students; and, Ir.) increases in student behavior problems.

Whatever the reason for decline, most schools become candidates for turnaround because of external pressures, such as the realization that students might not graduate for failure to pass a state exam (Szachowicz, 2010), or the possibility of entering the restructuring category under federal education regulations (Calkins et al., 2007). Laura Pappano (2010), the author of Inside School Turnarounds, defines a turnaround as follows:

School turnaround-this adrenaline-charged moment that we are presently in-is about rapid and dramatic improvement not just in test scores but also in culture, attitude, and student aspirations. It is marked not by orderly implementation but by altering a lot at once and being 
willing to step in and change-and change again. It is a new paradigm for education, one not about trusting the process but about seeking results, both measurable and immeasurable. (p. 3)

A 2007 report by Mass Insight defines a school turnaround "as the integrated, comprehensive combination of fundamental changes in program, people, conditions, and (sometimes, but not necessarily) management and governance required to interrupt the status quo and put a school on a new track towards high performance" (Calkins et al., 2007, p. 7I). A requirement of a turnaround under federal law is that gains in student achievement occur within two years followed by a period of sustained improvement and growth. Consequently, most observers view school turnarounds as a "distinct professional discipline that requires specialized experience, training, and support" (Calkins et al., 2007, p. 4).

Under the federal government's Race to the Top initiative, schools qualify for funding under the Title I School Improvement Grant program only if states have a process to identify their lowest-performing schools in low-income communities and transform those schools using one of the following intervention models (U.S. Department of Education, School Improvement Grant Program):

- Turnaround: Replace the principal and rehire no more than 50\% of the staff. The principal must have sufficient flexibility to implement a comprehensive improvement strategy.

- Restart: Convert or close and reopen a school under an alternative education management organization.

- School closure: Close a school and enroll students in a higher-achieving district school.

- Transformation: Engage in a change process that includes: I) replacing the principal and improving teacher and leader effectiveness; 2) improving instruction; 3) extending learning time and strengthening community partnerships; 4) providing school leaders additional autonomy, flexibility, and support.

There are examples of individual schools successfully adopting these intervention models, but they have not been taken to scale on a statewide or national level (Calkins et al., 2007). Case studies by Mass Insight include only a few years of promising test data with limited detail on the specific actions leaders took to change school culture and practices (Mass Insight, 2009a; 
2009b). At the school site level, a turnaround happens when teachers change the way they teach, students understand the school's vision and work harder to meet it, and effective leadership is in place to ensure progress (Elmore, 2004; Fullan, 2006; Pappano, 2010).

\section{The Role of Leadership in School Turnarounds}

The emerging research on turnarounds suggests that success requires effective leadership (Duke, 2008; Elmore, 2000; Institute for Strategic Leadership and Learning, 2012). The principal chosen to lead a turnaround must be an instructional leader who will focus on improving teaching and student performance, with an understanding that all other duties associated with school management support this primary responsibility (Elmore, 2000; Fullan, 2006). Successful turnaround leaders have high expectations for students, are called to the "moral mission" (Pappano, 20Io, p. 22) of providing a quality education to low-income, urban young people, and possess the persistence to overcome setbacks and support student achievement (Leithwood, Harris, \& Strauss, 2010). For Kanter (2004), "every turnaround starts with the same overriding challenge: the need to make unpopular decisions about a situation whose full ugliness has been denied, and yet, at the same time, restore people's confidence that they can start winning again" (p. I64).

Turning around a school requires a leader who can focus on what Wagner et al. (2005) define as the seven disciplines for strengthening instruction: I.) urgency for instructional improvement using real data; 2.) shared vision of good teaching; 3.) meetings about the work; 4.) a shared vision of student outcomes; 5.) effective supervision; 6.) ongoing professional development; and, 7.) diagnostic data with collaboration. Schools that have made rapid improvements are led by principals who galvanize "both individual and collective responsibility for the improved achievement of all students through a variety of deliberate improvement structures, expectations, practices and continuous feedback" (Institute for Strategic Leadership and Learning, 20I2, p. 6).

\section{Turning Around Failing High Schools}

Research suggests that turning around a high school is more challenging than an elementary or middle school, in part, because high school students are highly influenced by peers and parental involvement generally declines (Duke \& Jacobson, 20II). However, effective turnarounds are particularly important 
at the high school level because they shape students' futures "in starkly concrete ways, determining whether they struggle with poverty or find a road to financial and social stability" (Pappano, 20I0, p. 7). In their study of successful high school turnarounds in Texas, Duke and Jacobson (20II) explored how focused changes in ninth grade curricula, school schedules, academic supports, teacher teams for incoming freshmen, along with efforts to strengthen community engagement through orientation programs for transitioning middle school students improved student outcomes. Other high schools, such as Brockton High School in Massachusetts, have significantly improved school performance by implementing a structured literacy format in each classroom and tracking student achievement at the teacher level (Ferguson, Hackman, Hanna, \& Ballantine, 20Io; Jonas, 20II; Szachowicz, 2010).

In their study of 15 successful high school turnarounds, Ferguson et al. (20I0) identified five steps that were critical:

I. Accepting responsibility to lead change.

2. Adoption of a clear mission with focused priorities to improve student outcomes.

3. Strategies and plans for high-quality adult learning.

4. Development of quality standards to judge teacher and student work.

5. Skillful and continuous attention to implementing plans, monitoring progress, and providing necessary supports and incentives to change.

As outlined in the remainder of this study, each of these steps was critical to the turnaround at Cristo Rey Boston High School.

\section{A Catholic School Turnaround Model: Cristo Rey Jesuit High School}

The story of Cristo Rey Boston High School must be viewed in the context of the Cristo Rey movement and the founding of the first Cristo Rey school. In I996, after a lengthy feasibility study, the Society of Jesus (the Jesuits) opened a new school on the southwest side of Chicago called Cristo Rey Jesuit High

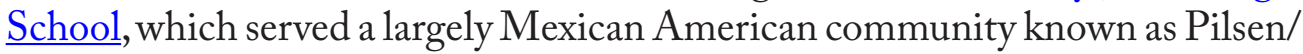
Little Village. During the feasibility study, which took place from I993 to I994, many parents told the Jesuits they were interested in sending their children to a safe Catholic high school because of the "poor performance, overcrowding, and sometimes dangerous conditions in local public schools"(Kearney, 2008, p.55).

The school was structured around a unique work-study program designed 
and implemented by Preston Kendall, a graduate of the Kellogg Graduate School of Business and a former insurance company executive who served as the first work-study director. Initially developed as a way to fund the school, the work-study program became an academic and experiential pathway to college that showed students they had a place in corporate America. Each student worked one 8-hour day per week, and once per month worked twice per week (Table I). Students worked five days or 40 hours per month and had 15 days of academic classes (Kearney, 2008). Teams of four students shared fulltime, 40-hour per week, entry-level jobs.

Table 1: Cristo Rey School Work Study Schedule

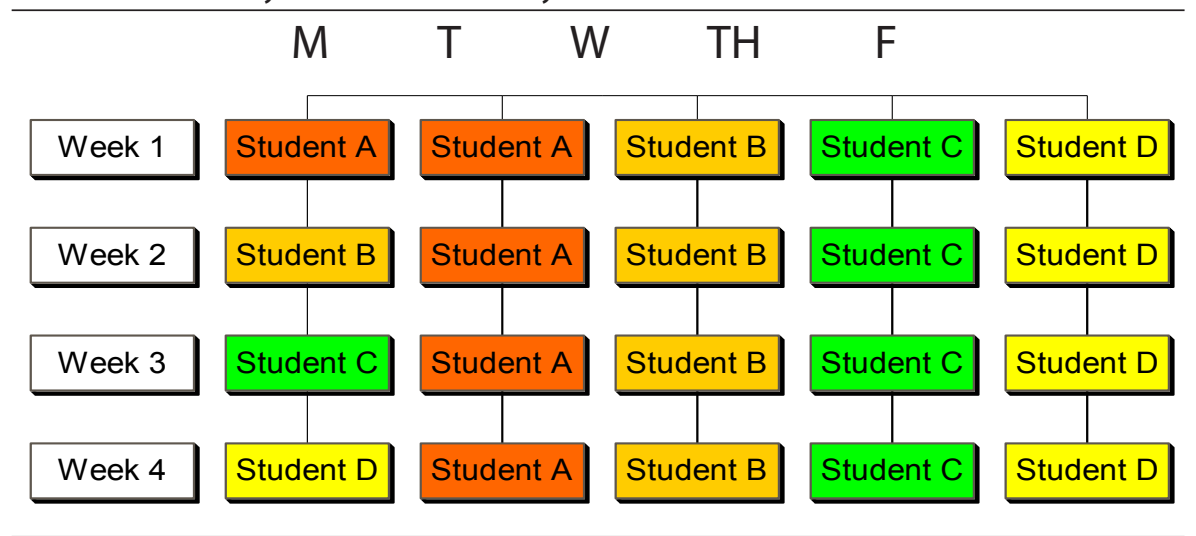

Performing needed entry-level duties in a corporate setting made the academic work relevant, taught them about the high expectations of the workplace, provided them with real-world experience and professional contacts, and showed students what was available to them if they completed high school and college. Established as a separate corporation from the high school and structured as an employment agency, the work-study business program employed each student and contracted their services to Chicago area businesses. During the summer, incoming Cristo Rey students engaged in an intensive 3-week training program where they learned basic office skills and etiquette, including proper attire, communications, and behavior (Kearney, 2008).

Cristo Rey students did not retain any of the money they earned; it all went to the cost of their college preparatory education at a private Catholic school. The program was designed to generate up to $70 \%$ of the school's operating costs, with remaining expenses raised through traditional fundraising from donors and foundations and a modest tuition charged each family based 
on their ability to pay (Kearney, 2008). A primary selling point for local businesses was that students would do real work that added value to the workplace. Underscoring this goal, businesses paid for student employees through their operating budgets rather than their charitable arm. Cristo Rey marketed the program as a way for companies to get work done and a means by which corporations could help urban youth receive a college preparatory education. The combination of doing real work that a corporation would pay for and using that income to afford a private, college preparatory education made the Cristo Rey model distinct from traditional high school work-study programs such as job shadowing, internships and mentoring, or career academies in which students take academic courses and classes that relate to an academy theme (Stern, Wu, Dayton, \& Maul, 2007; Stone \& Aliaga, 2007).

Over the course of their 4-year high school career, each student spent the equivalent of I academic year working in a business. While there has been no empirical study of the impact of the Cristo Rey work-study program on student learning, students from the high dropout neighborhood in Chicago who participated in a mandatory work-study program were showing up to school every day (Kearney, 2008). A report from Cristo Rey Network with data from the National Student Clearinghouse later would show that $87 \%$ of all Cristo Rey school graduates of the class of 2008 enrolled in college within I2 months of graduation from high school (Cristo Rey Network, 20Ira), a significantly higher college going rate than Latinos $(62 \%)$ and Blacks (56\%) nationwide who graduated high school in 2008, and a higher college going rate than Whites (72\%) nationally (National Center for Education Statistics, 20IO).

\section{Cristo Rey Jesuit High School's Academic Model}

Academically, Cristo Rey Jesuit High School was organized as a college preparatory high school (Kearney, 2008). The school's founding principal, Sr. Judith Murphy, OSB, and a committee of educators who advised her, understood that urban students needed a different academic experience than what was offered in a traditional high school. At the same time that Cristo Rey Jesuit High School was opening, the National Association of Secondary School Principals (NASSP) published Breaking Ranks: Changing an American Institution (NASSP, 1996). The report documented emerging research that concluded that high schools had become irrelevant for millions of young people, especially those who were poor. Breaking Ranks called for a curriculum that connected to "real-life applications of knowledge," assessments aligned with the 
curriculum, and individualized learning (NASSP, I996, pp. II-I9). The report, moreover, recommended that high schools create small units of no more than 600 students to improve relationships and student engagement, and urged school leaders to forge closer ties to businesses and community organizations (NASSP, 1996).

By 1999-2000, its fourth year of operation, the Cristo Rey Jesuit High School attracted considerable corporate and philanthropic support in greater Chicago. In January of 2000 the school opened a new facility, boasted a small endowment, and, most importantly, had graduates going to college. The school's success caught the attention of other Catholic educators who visited the Chicago school and sought to replicate the program in other cities.

\section{Replicating Cristo Rey Jesuit High School}

In June of 2000, venture capitalist B.J. Cassin visited Cristo Rey Jesuit High School and was moved by what he saw. Shortly after his visit he launched a foundation that would contribute \$12 million to the scale-up of Cristo Rey Jesuit High School across the country, and he hired me to run it. In $200 \mathrm{I}$ left Cristo Rey Jesuit High School, where I had served 3 years as development director, and moved back to Boston to manage the foundation out of an office at Boston College. In 2003, the Bill \& Melinda Gates Foundation made a $\$ 9.9$ million commitment to the replication effort, and three years later added another $\$ 6$ million to replicate schools and build the capacity of the national Cristo Rey Network office. The Cristo Rey Network was formally established as a $50 \mathrm{I}(\mathrm{c})$ (3) organization in 2003 and tasked with managing the growth and quality of the schools (Cristo Rey Network, 20rrb). Network staff worked with local agents to conduct feasibility studies for new schools, taught the work-study model to local leadership, conducted site visits to the original school, and gathered best practices that were emerging from the new schools.

Ultimately, the network office, which was located in Chicago, was responsible for ensuring that every member school adhered to the Cristo Rey Network Mission Effectiveness Standards, which defined the standards by which the schools operate. The Io standards (most recently revised in July 20I2) ensure that an individual school:

I. Is explicitly Catholic in mission and enjoys Church approval.

2. Serves only economically disadvantaged students. The school is open to students of various faiths and cultures. 
3. Is family centered and plays an active role in the local community.

4. Prepares all of its students to enter and graduate from college.

5. Requires participation by all students in the work-study program. All students must be I4-years-old on or before September Ist.

6. Seeks to integrate the learning present in its work program, classroom, and extracurricular experiences for the fullest benefit of its student workers.

7. Has an effective administrative and board structure as well as complies with all applicable state and federal laws.

8. Is financially sound. At full enrollment the school is primarily dependent on revenue from the work-study program to meet operating expenses. In addition, the school maintains a comprehensive advancement program to ensure financial stability.

9. Supports its graduates' efforts to obtain a college degree.

Io. Is an active participant in the collaboration, support, and development of the Cristo Rey Network.

From 2001 to 2009, the network oversaw 32 feasibility studies, which resulted in the establishment of 25 Cristo Rey high schools, all of which were located near large urban centers where there was a concentration of both students and corporate jobs. The feasibility study required new schools to secure commitments from potential corporate sponsors, identify school leadership, demonstrate an ability to adhere to the network's standards, and produce a plan to raise money. We gave little direction to local schools on how to establish their academic program. Principals of new schools visited Cristo Rey Jesuit in Chicago and other schools to learn about the academic schedule and to pick up copies of any written curriculum available, but each school developed its own approach to teaching and learning, just as the original school had done. In 2006 the network hired its first academic officer and began requiring new schools to adopt a standard curriculum framework and common assessments in 20Ir. These were developed by teachers and principals from several Cristo Rey schools.

\section{North Cambridge Catholic High School}

North Cambridge Catholic High School had a long history of serving Irish, Italian, and French immigrant families in Cambridge, Massachusetts and 
nearby communities. The school was originally St. John High School, which opened in I92I, and includes former U.S. House Speaker Thomas P. "Tip" O'Neill among its alumni (North Cambridge Catholic High School, 20og). The school was part of the central high school system of the Roman Catholic Archdiocese of Boston. Each central school had a governing board, with principal appointments and some financial support coming from the Archdiocese. Central schools covered most of their operating expenses with revenue from tuition and had advisory committees to help raise funds (North Cambridge Catholic High School, 2002).

By the I980s, North Cambridge Catholic High School, with its proud tradition of serving working-class and immigrant families, was drawing fewer students from rapidly gentrifying local communities that had been home to most of its students. Consequently, the school began to recruit young people from Boston, Chelsea, Everett, Revere, and other cities. Within a decade, the majority of students were Latino, African American, Cape Verdean, Haitian, and Vietnamese. The school's enrollment averaged around 250 students, and the school marketed itself as a place where young people with no other option could receive a quality education (North Cambridge Catholic High School, 2002).

In 200I, the Archdiocese announced that by 2004 its annual subsidies to the central Catholic high schools would go away, the Archdiocesan Central School Board would disband, and each school would be expected to be financially self-sufficient (North Cambridge Catholic High School Self Study, 2002). In 2002, Thomas P. O'Neill, III, a former lieutenant governor of Massachusetts, chair of the school's Board of Advisors, and school alumnus, proposed converting North Cambridge Catholic to a Cristo Rey school. The timing was ideal because the Sisters of Notre Dame de Namur had just studied the feasibility of opening a Cristo Rey school in either Boston or Lawrence, a city just south of the New Hampshire border that happened to be the poorest municipality in New England (North Cambridge Catholic High School, 2002). The Sisters' decision to open a school in Lawrence left greater Boston, a larger metropolitan area with more potential for corporate placements, open to North Cambridge Catholic High School.

\section{North Cambridge Catholic High School becomes a Cristo Rey School}

In the summer of 2002, North Cambridge Catholic High School conducted a self-study to determine if the school could become a Cristo Rey school. Fr. 
Jose Medina, a newly ordained priest who taught at North Cambridge Catholic High School during the 2000-200I school year before earning a master's degree in education from Harvard University, wrote the study report (North Cambridge Catholic High School Self Study, 2002).

In early 2003, North Cambridge Catholic High School gained membership in the Cristo Rey Network, which authorized the distribution of \$1,253,000 of Gates and Cassin funds to the school over a 4-year period to hire new staff, purchase vehicles to transport students to and from their placements, and train students for work. The school's new work-study director, Terry Gupta, worked to ensure that the practices of the original Chicago program were implemented in Cambridge. A new dress code that required students to dress professionally at school and work was put in place, and students could not participate in athletics on the days they worked. Moreover, the school could no longer accept undocumented students because the program required that every student be eligible to work.

\section{North Cambridge Catholic as a Cristo Rey school: 2004-2007}

North Cambridge Catholic had 234 students in 2004-2005, its first year as a Cristo Rey school (Cristo Rey Network, 20IIa). Sr. Ellen Powers, CSJ, the school's long-term principal, was now president, Bob McCarthy, the assistant principal, became the principal, and David Paskind, who had taught at the school for many years, became the assistant principal. In a Cristo Rey school, like many Catholic schools, the president is the head of the institution responsible for maintaining the school mission, and is accountable to the Board of Trustees and the religious sponsor (James, 2009). The president is the school's primary representative to external audiences and is responsible for the school's finances. The principal oversees the academic and student life program, and is co-equal on the organizational chart to the work-study director, development director, and chief financial officer. This structure frees the principal from spending time on fund-raising and external issues (James, 2009).

In 2006, after 2 years as the head of school under the new model, Sr. Ellen Powers, CSJ, was asked by her religious congregation to move into a leadership position within the order, and Bob McCarthy became acting president and principal. In the spring of $2007, \mathrm{McC}$ arthy was named president of the school, and he hired Fr. Jose Medina, who had returned to Boston after working for 4 years at an all-girls Catholic high school in Washington, DC, to be the school's principal. 


\section{The New Leader Finds a School in Decline}

Fr. Medina began work on July I, 2007, and immediately scheduled individual meetings with all I8 faculty members to learn about his staff and to gain a deeper understanding of the school he was about to lead. The meetings confirmed what he suspected - the school was in decline. Faculty and staff told Fr. Medina that the school was successful because each year top graduates went to prominent universities, and the school maintained a strong and vibrant community spirit. Medina, however, learned that teachers chose what they would teach in their subject area and determined on their own to what degree to monitor student progress toward specific learning goals. There were no tools for aligning the curriculum with state standards, or even to align the curriculum across grades and within each grade.

Because the Cristo Rey Network required it, all students took the Iowa Test of Educational Development (ITED), and many took PSATs and SATs. When Medina asked his teachers if they ever looked at the data, some told him they used it to identify where students needed additional support but there was no systematic analysis of test scores, nor was the data used to make changes to instruction.

He learned that a faculty planning committee, which met monthly, often advocated for professional development, but had limited success making any substantial changes to the staff development program or the curriculum itself. Grade level meetings focused on discipline issues and academic failures rather than improving teaching and learning. Teachers were rarely observed or evaluated; a good teacher was one who could maintain discipline in the classroom. There were six 6o-minute periods a day with no study periods, no double blocks, and no difference in the time allocated per subject. The transition to the Cristo Rey model had given teachers more free periods, but the schedule did not permit common planning time with other teachers in their discipline or grade level, and students were often not available when teachers had a free period.

Most significantly, Medina learned in his interviews with staff that they did not believe students could achieve at higher levels and were not taking responsibility for student learning. It was common for teachers to say, "I taught it, but the students didn't do their homework or didn't study enough."

Turnaround Stage r: Creating Conditions for Improvement, 2007-08 
Prior to the start of the 2007-2008 school year and after meeting with each faculty member, Medina decided to make several changes, which were announced at a faculty meeting in August. First, he lengthened the school day by I5 minutes and eliminated the rotating schedule so each class could be taught at the same time each day. He also added three professional days to the schedule to focus on ways to improve instruction. Medina then set up email accounts for all faculty and students so they could communicate with one another, and he announced that grades would be available online to improve transparency for students and parents. Finally, Medina shifted many of his administrative responsibilities to the assistant principal, David Paskind, so he could focus on developing a strategy to improve instruction.

In addition to meeting with his teachers, Medina spent the summer analyzing the school's scores on the ITED, which he presented to the faculty at the August meeting. He showed that the majority of students graduating from the school were below grade level and had not advanced a full academic year in each of the 3 years they took the ITED. This was especially troubling since the class of 2008 had spent all 4 years as students in the Cristo Rey program. The faculty doubted the scores. "Many of us criticized the test and questioned what the results were telling us," English teacher Carrie Wagner explained. "It didn't seem possible that our students were making such little progress."

\section{Setting the Stage for Change: Effective Models and Data Analysis}

During a professional day in October 2007, Medina decided to send all of his teachers to a number of high-performing charter schools in Boston, including some of the middle schools that were feeders to North Cambridge Catholic High School. Many of the teachers visited the MATCH Charter School, which served students in grades nine through I2, and two middle schools, Roxbury Preparatory Charter School and Excel Academy. The three schools served low-income students and had impressive outcomes improving students' academic achievement.

At the MATCH School, North Cambridge teachers learned about a proficiency test the school used to assess the math and literacy skills students needed to master prior to entering ninth grade. The proficiency program was designed to remediate students who were not at grade level. MATCH also offered Advanced Placement (AP) courses and required all students to take one AP class during their junior year and at least one AP or college course during their senior year. The teachers saw students from low-income backgrounds- 
the same students they taught—-taking AP classes. "Why can't we do this?" wondered Wagner.

The visits to Roxbury Prep and Excel Academy sparked a conversation about changing the freshmen curriculum. The two middle schools offered double block classes of math and language arts so that students could have enough time to study the subject matter. For mathematics, the charter schools offered one class in math skills followed by another in problem solving. In English, Roxbury Prep and Excel Academy offered one period for reading and another for language arts. At a meeting of Cristo Rey Network principals in October of 2007 , Medina talked to school leaders who had doubled the time for math and language arts in the freshman year.

Fr. Medina met with the staff of the New England Regional Office of the College Board in Waltham, Massachusetts, to get a better understanding of what was expected of students when they entered college. Their advice was to intensify the ninth grade experience and add AP classes as soon as possible in the upper grades. His discussions with College Board confirmed what the faculty learned at the MATCH School. Adding AP courses would soon have some empirical research to support it. A College Board study by University of Texas researchers concluded that students who took at least one AP course and test had higher college GPAs and graduation rates than students who took no AP courses (Hargrove, Godin, \& Dodd, 2008). "The AP classes would give us the right target," explained Medina. "We needed to start with the end goal and work backward to accelerate learning so that students could be ready for AP level work in their senior year."

\section{Confronting Reality: Fall 2007 ITED Results Show No Change}

When the results of the 2007 ITED came back in November, they reaffirmed what Fr. Medina noted earlier (see Table 2). The Normative Curve Equivalent (NCE) scores measure where a student falls on a normal curve, indicating the student's rank compared to other students on the same test. The scores of the class of 2008 , the seniors that year and the first group in the converted school to experience all 4 years under the Cristo Rey model, were particularly troubling. In the fall of 2007, the class of 2008 scored 264.7 in reading, which placed them below the roth grade level (more than a year behind where they needed to be) and again meant they had made less than a year's worth of academic growth since the previous year's ITED. 
Table 2: Report of Fall 2007 ITED Normative Curve Equivalent Scores

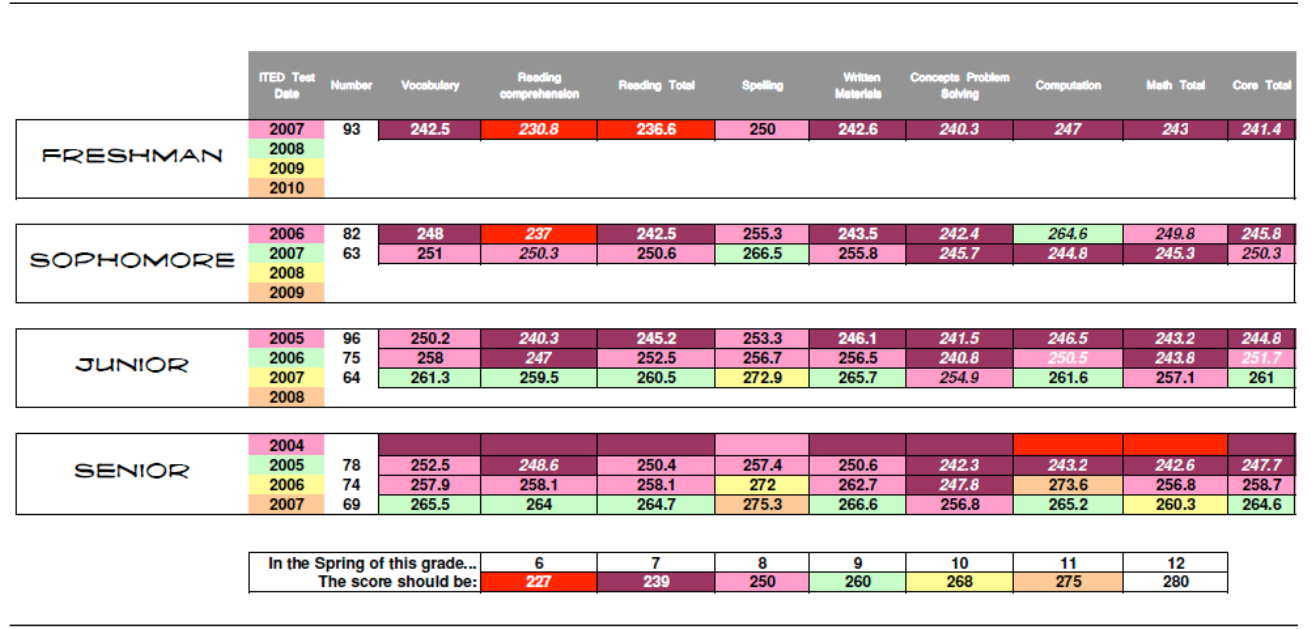

Note: Each color represents where a student should be by the end of each grade. For example, a ninth grader should be scoring 260 and is marked by light green. The majority of freshmen scores were in the $6^{\text {th }}$ and $7^{\text {th }}$ grade reading and math levels, scores marked by a pink or dark red purple color.

The class had a median NCE raw score of 250.4 (equivalent to eighth grade) in reading as sophomores. When they took the test in the fall of 2006 as juniors, their median NCE raw score was 258.I in reading, still below ninth grade levels. The math results were similar, and the same trends were found for the sophomore and junior classes. No changes had been made in the curriculum to respond to this data. "When I reflected on the data, I felt extremely betrayed," said Wagner. "What the data revealed, if we bothered to look at it, was a failed endeavor. I had dedicated 6 years to the school, and to find out that we were not doing a good job was really devastating." After initially doubting the ITED analysis, math teacher Jill Crowley reached a similar conclusion. "I felt at times that we were doing a disservice to kids," said Crowley. "We were not pushing them enough. For example, in Algebra I, we were not covering a full year of course work. Something was wrong, and Jose's (Fr. Medina) analysis made it clear that we had to change."

The dispute over the validity of the ITED scores was over. "The November meeting was the first time that I had the impression that the majority of teachers realized that even though they were trying hard to serve our kids, it was not enough," said Fr. Medina. "They had seen other schools teaching the same kids we teach and doing a much better job. There was no doubting what the ITED scores were saying. Now we could talk about what we needed to do." 


\section{Towards a College Preparatory Experience}

Fr. Medina began a professional development workshop by asking teachers to reflect on four questions:

I. How do I teach my students cognition (the intellectual process of gaining knowledge) within my discipline?

2. How do I model for my students the act of knowing?

3. How do I help students know and experience the things I see and say in my subject matter?

4. How does what I teach increase my students' consciousness of themselves?

Over the course of a 3-hour workshop, the focus was on assessments. The first activity involved teachers reviewing the ITED exams and looking closely at sections that had to do with each teacher's subject area. Teachers met in small groups according to their subject area and discussed the logic behind the test questions, including what the questions were asking the students to demonstrate. The teachers then discussed strategies they could implement in their classes to help students be better prepared to answer the ITED questions. The second hour involved teachers taking a look at their own assessments and comparing them to the standards of the College Board. The teachers discussed their assessments in small groups and then reported to the larger group. "By this point, we realized we were all over the place when it came to assessments," said Crowley. "And, we learned that the ITED was asking questions that our students should have been able to answer if we had prepared them properly." In the final hour of the assessment exercise, teachers took one of their assessments and redesigned it based on the criteria developed from the small group discussion on the ITEDs.

Fr. Medina ended with a presentation entitled "Where are we headed? Towards a College Prep Experience." He laid out a plan entitled "Coherence, Rigor and Relevance," which called for consistent grading policies, consistent expectations of what good work looks like, scaffolding in which the teacher models the desired learning strategy and then shifts responsibility to students, and common assessments. He announced that the school's primary focus would be on English and mathematics, and he explained that the schedule needed to change to accommodate double-block courses in math and Eng- 
lish for all freshmen and the introduction of AP courses during the students' senior year.

Medina wanted to be sure his faculty understood that he and they together were creating a new school. He believed in his students' capacity to do better academically, and he wanted to be sure his teachers did as well. After calling all teachers to school after a snowstorm on December 20, 2007, Fr. Medina was forced to address open challenges from his staff. Toward the end of the day, Medina wrote the staff an email telling them, "We are different. We choose to rise above an educational system that has already failed our students." He went on to point out that the ideals of helping all students learn came at the "price of determination," which "can only be understood by our students and families when they see it in us." Medina ended the email by saying:

A group of educators becomes a community when they start thinking of each other as part of the same thing ...As a community, we have a long road ahead with many tough decisions and difficulties to face. We will overcome only if we choose to rise above, pour our hearts into it, and walk together. I know it is possible; since with God's help nothing is impossible. I don't give up and will be here plowing through the difficulties, no matter what!"

"In some ways, it was a defining moment,"Wagner said. "Though I didn't particularly like the approach, the point had been made. We were becoming a much different school."

Fr. Medina continued to use every piece of data he could find to support the need for changes to the curriculum and to the way teachers taught. In February of 2008, he presented a report to the faculty from the National Student Clearinghouse (NSC) on the college going rates of the school's recent graduates. While the school touted the fact that all students were accepted to college, not all were enrolling in college upon graduation. There was some good news, however. The class of 2007, which experienced 3 years under the Cristo Rey model, had $69 \%$ of its members enroll in college upon graduation. Fr. Medina's previous evaluation of the school he inherited caused him to conclude that the work-study program, not the academic program, gave students the confidence they needed to go to college, and that the only way to increase this number further was to bolster the school's academic efforts. 
Figure 1: Percentage of Cristo Rey Students Enrolled in College During the Fall Immediately following Graduation, 2003-2010

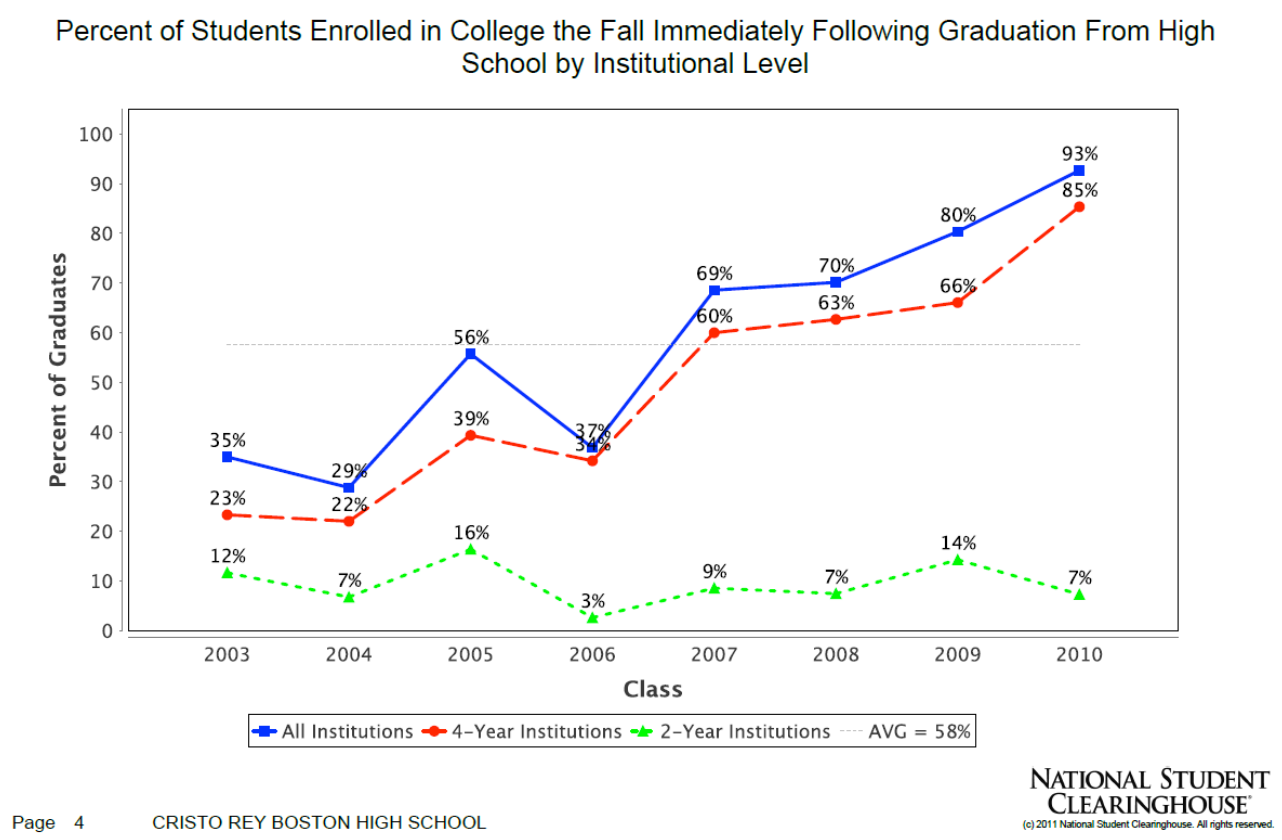

In February of 2008, Medina met with parents of freshmen and sophomores whom he had come to know in his first months at the school. He talked with them about the coming academic changes, explained the work the faculty was doing, and explained the need to lengthen the school day. They were in favor of the changes and did not object to the longer day. With the support of parents, Medina presented an outline of the school's academic plans to the Board of Trustees, which supported his efforts. These included double block classes ( 96 minutes per day) of math and language arts for all ninth graders and a proficiency program after school and during study halls to remediate skills students did not have when they entered the school; the introduction of college level work in the senior year through AP courses; extending the school day to 3:05 p.m.; and extending the school year by one week.

In the spring of 2008, as he was planning the 2008-2009 school year, he asked three faculty members to join him in the leadership of the academic program: Wagner (humanities); Crowley (math); and, Leanne D'Alessandro 
(science). The three were junior to many of the teachers they were now leading. Crowley and Wagner remember that many faculty members were skeptical that Medina's plans would work, but most were excited that the school finally had an academic plan. By showing the faculty the ITED and NSC data, enlisting teachers to do research with him on other high-performing schools, and by knowing the strengths and weaknesses of his teachers, he was able to position the school for significant change. He did not ask teachers to step down, but he made it clear that the demands of teaching would become more intense. Under Fr. Medina's leadership, teachers were at the forefront of the turnaround efforts that would shape the school in the coming years.

\section{Turnaround Stage 2: Maintaining Survival and Realizing Improvement, 2008-20I2}

Wagner and Crowley spent part of the summer of 2008 designing common assessments for the algebra and English courses the incoming freshmen would take during the 2008-2009 school year. They also developed proficiency exams in math and English based on Massachusetts state standards to assess the skills students had to master by the end of eighth grade. Because they wanted to be sure students had the skills needed to do college preparatory work, Crowley, Wagner, and Fr. Medina decided that the passing grade for a proficiency test would be $90 \%$. Students had the opportunity to take a different version of the exam every month until they passed, and remediation would be based on the weaknesses identified on the proficiency test.

The remediation plan evolved over the course of 2008-2009. In January of 2009, 4 months into the year, only $2 \mathrm{I}$ students had passed all three proficiency tests. In February, the school began an after-school remediation program designed to teach the skill deficiencies identified in the proficiency exams. All students who scored below $70 \%$ (about 60 at the time) were required to take I hour of remediation per week. The remediation program included general instruction, practice, and tutoring. Many students, however, still had trouble attaining the required score, often because they found difficulties in a specific area. By the spring of 2009,45 students had not passed the three proficiency exams and were assigned an adult tutor or a peer tutor who had already passed the test. Tutoring took place before and after school. Eventually, every student had a tutor, and as a result 38 of the remaining 45 students passed the proficiency exam by the end of the year.

Increased classroom time made it possible for students to have a deeper un- 
derstanding of freshman math and English. By second semester, math teachers reported that ninth graders were more comfortable with problem solving activities than previous groups of first-year students. In English, every student participated in literature circles where they read a book with a small group of peers and conducted student-led discussions to uncover key plot and character developments as well as themes, tone, and literary elements. The goal was for students to build skills in independent learning.

In addition to the new freshman curriculum and remediation program, in 2008-2009 the school implemented many of the strategies from SpringBoard, a comprehensive program developed by the College Board to prepare students for AP courses. The SpringBoard curriculum and the professional development provided by SpringBoard trainers gave the faculty a wealth of teaching strategies geared toward developing critical thinking skills. Additional AP classes in studio art, macroeconomics, and U.S. government were created and by the 2009-2010 school year every senior had to take at least one AP class.

The freshman English and math teachers held weekly department meetings to discuss teaching, design lesson plans, and grade common assessments. In both departments, teachers graded one another's students to ensure consistency and fairness. The weekly meetings not only supported the implementation of the new initiatives but also provided a fertile ground for many conversations around assessment, teaching, and learning. "The weekly meetings were a significant change for us," said Crowley. "It standardized what teachers accepted as quality work and allowed organic discussions about which teaching techniques produced the best results."

Figure 2: Ninth Grade ITED Growth

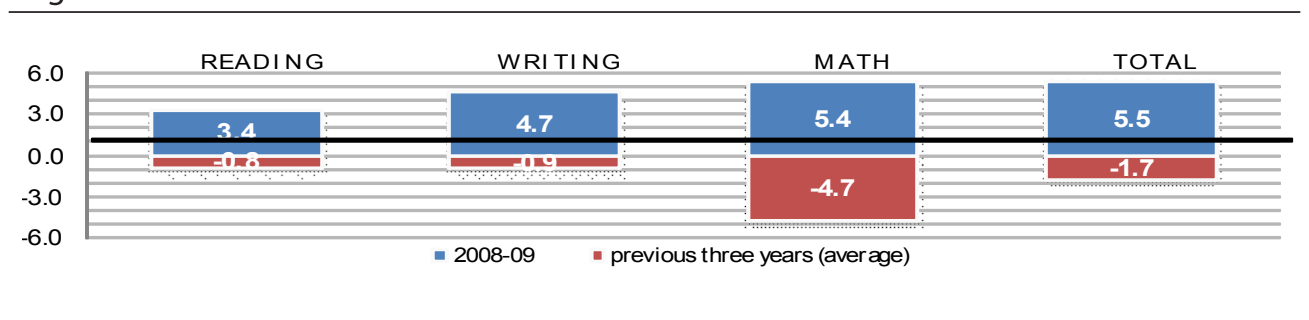

Note: Student Growth on ITED as measured by Normative Curve Equivalent

Rather than wait until the fall of 2009 for the freshmen class to take the next ITED, ninth graders took the spring ITED and showed impressive gains (see Figure 2). Using the normative curve equivalent (NCE) as a measure of student growth, if all students were to make I year of progress, their NCE gain 
would be zero. A comparison of the spring to the fall test results showed that ninth grade students posted substantial academic gains by the spring of 2009: 3.4 NCE in reading; 4.7 in writing; and 5.4 in math; and an overall academic gain of $5.5 \mathrm{NCE}$ points in the core total. Students gained more than one academic level during the year, few students showed an academic loss, and several students showed academic gains of 25 points and above. When taking into account previous year's data, these academic gains were statistically significant.

\section{A Financial Crisis and Structural Change}

In 2008-2009, the year North Cambridge Catholic High School launched its new academic program, the school had 282 students, well below the 400 student target set in the original feasibility study (Cristo Rey Network, 20Ira). The national economy was in a tailspin, and the school struggled to find workstudy jobs. The school would run an operating deficit for the third consecutive year, and the board authorized the use of reserve funds to make ends meet. From 2007 to 2009, the school used more than \$I million in reserves to cover operating losses, reducing the school's once comfortable savings to approximately \$100,000.

The Board of Trustees, which enthusiastically supported Fr. Medina's effort to improve academics, struggled to get accurate information on the school's financial picture and consequently approved budgets with unrealistic revenue assumptions. Fr. Medina, alarmed by the school's economic condition, met with Tom O'Neill. In the fall of 2008, O'Neill called and asked me to take a look at the school and provide the board with a report.

I made a number of recommendations to stabilize the school financially, including the elimination of five positions. The school president wanted to wait, and the board, realizing that a change in leadership was needed immediately, asked me to take over as interim head of school in January of 2009. For the next 6 months, I continued my work at the national Cristo Rey office and oversaw North Cambridge Catholic High School. In April of 2009 the board asked me to be the school's president, and I accepted. At the same meeting, the board approved my plan to restructure the school, which resulted in a net loss of I0.25 positions, $25 \%$ of the staff I inherited 6 months earlier. I hired new leadership for the work-study and development departments and focused on finding work-study placements, which were critical to the school's operating needs. While we eliminated many positions, we remained committed to the academic turnaround. 
Table 3: North Cambridge Catholic Reorganization: January to June 2009

\begin{tabular}{|c|c|c|c|}
\hline Department & Positions Eliminated & Positions Added & Net Loss \\
\hline Development & $\begin{array}{l}\text { Development Director, } \\
\text { Sr. VP, } \\
\text { Executive Assistant, } \\
\text { Grant Writer (.5), } \\
\text { Leadership Society (.5) } \\
\text { (4.0) }\end{array}$ & $\begin{array}{l}\text { Director } \\
\text { (1) }\end{array}$ & 3.0 \\
\hline Business & $\begin{array}{l}\text { CFO } \\
(1.0)\end{array}$ & $\begin{array}{l}\text { Financial Consul- } \\
\text { tant }(.25)\end{array}$ & .75 \\
\hline Work Study & $\begin{array}{l}\text { Director, } \\
\text { Business Development } \\
(2.0)\end{array}$ & $\begin{array}{l}\text { Business Develop- } \\
\text { ment (1), Director } \\
(1) \\
(2.0)\end{array}$ & 0 \\
\hline $\begin{array}{l}\text { School } \\
\text { Support }\end{array}$ & $\begin{array}{l}\text { Nurse, } \\
\text { College Counselor, } \\
\text { School Counselor, } \\
\text { Volunteer Coordinator (.5), } \\
\text { Assistant Admissions (.5), } \\
\text { Maintenance (.5), } \\
\text { Associate Principal (reduced to .5) } \\
\text { (5.0) }\end{array}$ & $\begin{array}{l}\text { Director of Coun- } \\
\text { seling and Well- } \\
\text { ness } \\
(1.0)\end{array}$ & 4.0 \\
\hline Faculty & $\begin{array}{l}\text { Three teaching positions } \\
\text { ( } 2 \text { math/language) } \\
\text { (3.0) }\end{array}$ & $\begin{array}{l}\text { Part time Spanish } \\
\text { teacher } \\
\text { (.5) }\end{array}$ & 2.5 \\
\hline Total & 15.0 FTE positions eliminated & 4.75 & 10.25 \\
\hline
\end{tabular}

\section{Continued Success through Transparency and Rebalancing Priorities}

While the school focused on improving the academic program, the workstudy program suffered significant job and revenue losses. Tom O'Neill and I invited Terry Gupta, the original leader of the work-study program, to help the school find work-study jobs. From January of 2009 through June of 20II Gupta and O'Neill signed 69 new corporate employers. Our success proved that a Cristo Rey school could succeed in greater Boston, even in a difficult economy.

Since we were attempting a turnaround at the same time we were cutting positions, we realized we had to keep faculty and staff apprised of the changes being made. I made several presentations to all staff to explain in detail the school's fiscal situation, and we benchmarked the school's fund-raising and job procurement performance to other Cristo Rey Network schools. I established 
the practice of distributing a monthly dashboard to faculty, staff, and board members detailing the school's progress on academic, work-study, development, financial, and other goals. The practice continues to this day.

During the 2009-20I0 school year, we made changes to the work-study training program, worked relentlessly to develop relationships with supervisors and other contacts at corporate partners, and saw a $20 \%$ gain in revenue from the corporate work-study program. By the 20II-20I2 school year, Cristo Rey Boston High School generated \$1.9 million in revenue from the work-study program, a $74 \%$ increase from 2008-2009. The school increased its annual development revenue for operations and in June of 2012 celebrated 3 consecutive years of modest surpluses, news that gave confidence to trustees and benefactors.

Changes took place in other areas of the school as well. For the first time, all staff received written evaluations, a new, more personalized admissions process developed by Fr. Medina was instituted, the college and personal counseling programs were revamped, Graduate School of Social Work interns from Boston College helped do twice yearly mental health check-ins with all students, and the school began a volunteer program in which recent college graduates lived in a former rectory, received a small stipend, and gave a year of service to the school.

I focused on ensuring that the school adhered closely to the Cristo Rey mission, particularly to the goal of serving the lowest-income students we could find. The average family income of the incoming ninth graders would drop from \$41,882 during 2008-2009 (Cristo Rey Network, 2008) to \$26,013 in 2OII-I2, the lowest in the Cristo Rey Network (Cristo Rey Network, 20IIa). In the fall of $2011,82 \%$ of our incoming students qualified for the federal free/ reduced lunch program.

\section{The Move to Boston}

The most significant change was the school's move to a new location across the street from a subway stop in Dorchester, the largest section of the city of Boston. We had outgrown our building in Cambridge, and with more than $70 \%$ of our students from the city of Boston, we needed to be closer to the students and families we were serving.

By September 2010 we completed a \$I.5 million renovation of a former Catholic elementary school with revenue from the sale of the Cambridge site, donated labor and materials, and funds raised from foundations and individu- 
als. A force of 576 volunteers packed and unpacked books and materials from the old school, patched and painted all 20 classrooms, installed white boards, painted hallways, refinished woodwork, and assisted with landscaping.

The school was renamed Cristo Rey Boston High School, the national logo was adopted as the school's logo, and a new mission statement calling for the school to educate young men and women of "faith, purpose and service" was drafted. By the start of the 20II-20I2 school year, the entire management team, except Fr. Medina and me, was new, and only a handful of staff had taught or worked in the former North Cambridge Catholic High School.

\section{Fostering Teacher Effectiveness}

Fr. Medina, Crowley, and Wagner continued their effort to improve instruction at a time when education policy shifted toward research suggesting that teachers are the most important school-level factor in student achievement (Clotfelter, Ladd, \& Vigdor, 2007; Gordon, Kane, \& Staiger, 2006). In December of 2009, Wagner and Fr. Medina attended a training sponsored by Uncommon Schools in Albany, New York to learn new faculty professional development methods. During the 2010-20Ir school year, the leadership team focused its efforts on improving pedagogy, including the quality of assessments and assignments, and the pacing of classroom activities. The school added more doubleblock courses, continued to require all seniors to take at least one AP course, and installed Smart Boards in all classrooms. Crowley and Wagner also met individually with each teacher in their department to review curriculum and teaching strategies. The faculty professional development program included the following:

- Twice-monthly, 2-hour faculty meetings in which teachers analyzed the effectiveness of methods learned from Uncommon Schools and SpringBoard trainings.

- Two daylong professional development sessions during the year and three daylong sessions at the end of the school year to analyze midterm and final exams.

- A weekly memorandum with teaching insights provided electronically by the principal.

- Informal and formal unscheduled observations, as suggested by Kim Marshall, a highly regarded former Boston school principal who edits a weekly newsletter on best practices in education. The observations were done 
regularly by department heads and the school principal.

- Coaching of all teachers by department heads trained in the Springboard program.

Additionally, the faculty began an audit system that encouraged teachers to visit other classrooms to view the teaching techniques of their colleagues. Visiting teachers provided one positive and one critical comment on the class they observed, noted the use of classroom management skills learned in the professional development trainings, and reported these comments to the observed teacher and designated department heads.

Wagner and Crowley had been coordinating the freshman remediation program, but the burdens of running the after-school program, coaching new teachers, writing curriculum, and helping to manage professional development took their toll. In 20I0-20II, we hired a full-time director of academic support, who oversaw the remediation process, recruited and trained tutors, and coordinated individualized education plans (IEPs) for students. In the spring of 20II, Wagner was appointed dean of curriculum and Crowley became dean of instruction and student life. Each would teach one class and be tasked with improving the quality of instruction throughout the school.

During 20II-20I2, Crowley and Wagner developed specific intervention plans for teachers who struggled, and they began work on a 2-year project to develop a written sequence aligned with PSAT/SAT data and the new Common Core Standards. In addition, Crowley took responsibility for drafting a document outlining what excellent teaching looks like at Cristo Rey Boston High School. The principal and deans observed teachers and gave feedback to each one I4-I6 times per year. A system in which each teacher is evaluated twice per year in a process that involves self-assessment and an assessment by the principal and deans was implemented. The goal of the observation and evaluation system was to create a culture of ongoing reflection and continual learning.

\section{Turnaround Stage 3: Continuous Improvement}

During the 20II-20I2 school year, Cristo Rey Boston High School had a population of 3II students, $49 \%$ of whom were Latino, $44 \%$ African American, with an average family income of $\$ 26$, OI3 and household size of 3.7 (Cristo Rey Network, 20Ira). The class of 2012 experienced 4 years of the new academic 
program and made substantial improvements.

An analysis of PSAT composite scores from sophomore year showed that the graduating classes of 2009, 20I0, and 20II scored at or below the national average for Black and Latino students of rog2. When comparing the last 3 nonproficiency years to the first 2 years of students to undergo the new ninth grade program (classes of 2012 and 20I3), the latter increased the average composite by $8 \%$ (see Figure 3). The drastic and consistent increase over 2 years was evidence that the new freshman program was working. After I year in Cristo Rey Boston's freshman academic program, students who entered high school below grade level were able to beat the national average for Black and Latino students.

We required all of our seniors to take SAT tests, something only seen in Boston's elite high schools. From 2009 to 20II, our average SAT scores were below the national average of Latino and African-American students. In the fall of 2oIr, however, our senior class, the first group to undergo the new curriculum, scored 80 points above the national average for students of color (see Figure 4). The improved scores confirmed that what we had been doing for the past 4 years was working. In addition, for the third straight year, every senior was accepted to one or more 4-year colleges. Of the class of 20II, only three students did not enroll in a 4 -year college upon graduation. One went to a 2-year community college, and two joined the military.

\section{Looking Forward}

We are still very much a school in a turnaround. Our biggest challenge has been that only slightly more than half of the students who start with us as freshmen will graduate 4 years later. Each student who leaves our high school is counseled into another school, and it is rare for a student who leaves our school to drop out of high school altogether. We are not satisfied, however.

The challenge we face is similar to other Cristo Rey schools. Of the entering ninth graders of the class of 20II, $53 \%$ remained at our school through graduation, and nationally $52 \%$ of ninth graders graduated from a Cristo Rey school 4 years later (Cristo Rey Network, 20Ira). The majority of students who leave Cristo Rey Boston and the other Cristo Rey schools do so because of academic reasons.

To become a successful turnaround, we need to retain more students, which requires us to do a better job of responding to the needs of our lowest-per- 
Figure 3: PSAT Composite Scores

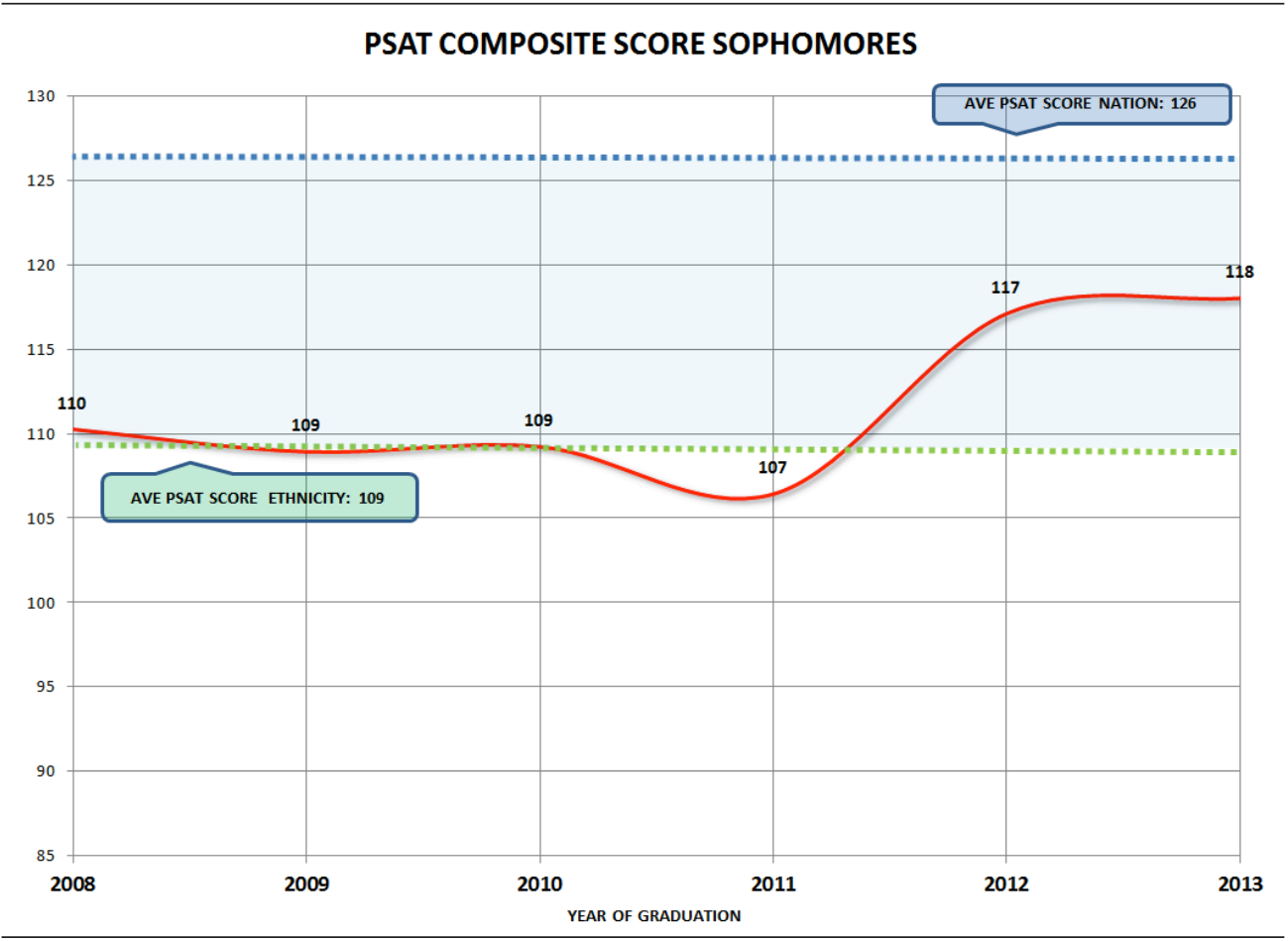

Figure 4: SAT scores of Cristo Rey Boston High School, Classes of 2008 through 2012

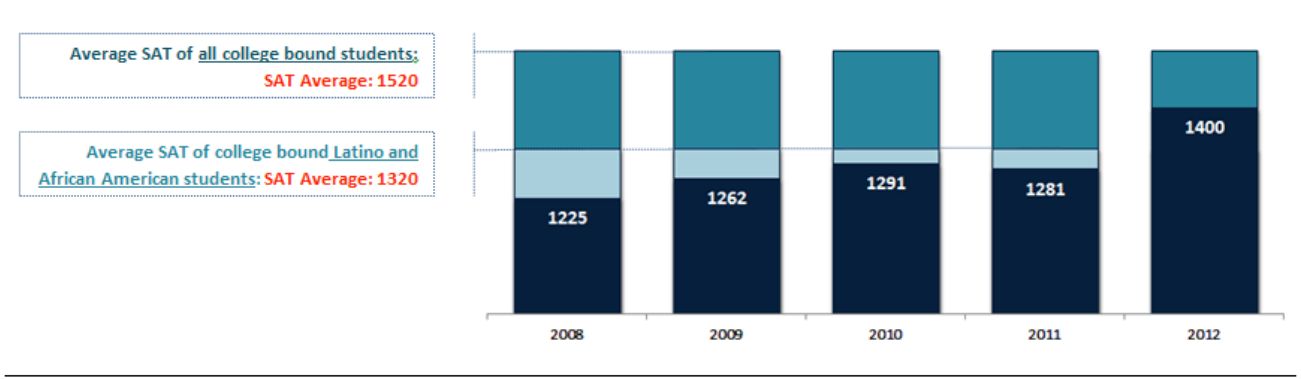

Note: Dark blue $=$ Cristo Rey Boston scores; Light Blue $=$ average SAT scores of Black and Latino students; Medium Blue = average SAT score nationwide and is essentially the achievement gap between students of color and white students.

forming students. "Rapid Achievement Gain Schools," defined by the Massachusetts Department of Elementary and Secondary Education for their ability to close the achievement gap more quickly than other schools, have a "well-orchestrated system of ongoing data collection and analysis that informs 
a continuously responsive and adaptive system of tiered instruction directly attentive to students' specific academic needs" (Institute for Strategic Leadership and Learning, 20I2, p. IO). Our goal in 20I2-20I3 is to build on our proficiency program by implementing a new reading program for ninth grade students. Our teachers will undergo a training program in literacy as well, and over time we will add more staff to serve students with learning differences.

We remain excited about partnering with other high-performing schools to learn and improve. In 20I2-2013, our teachers will work with faculty from Boston Collegiate Charter School and a nearby public school, the Burke High School, to align our curriculum with the new common core state standards. Our goal is to be the very best school in Boston for students who, upon entering high school, are reading and doing math one to two grades below level. We want to prepare every one of these students to enter and graduate from college.

\section{Putting the Cristo Rey Boston Turnaround in Context}

Cristo Rey Boston High School's turnaround was not driven by a standardized test requirement, state regulations, or the potential loss of state or federal funding. No one came from the outside and mandated a turnaround. The Cristo Rey Boston turnaround was about fulfilling a mission deeply embedded in the school community, rather than an effor by outsiders with a lofty but detached vision. Change came because the principal and eventually the faculty came to a better understanding of the effective practices associated with successful schools. The Cristo Rey Boston turnaround meant taking on a proud culture not open to looking honestly and critically at data.

A 2010 report from the Century Foundation suggests that school turnarounds require a change in the parent and student mix at the school (Kahlenberg, 20Io). Their researchers argue for the creation of schools that have middle- and lower-income students. Cristo Rey Boston High School, which now serves more low-income students than it did previously, is a compelling challenge to that assumption.

A critical difference from other turnaround efforts is that because change was not mandated from an outside group, Cristo Rey's turnaround felt organic and bottom-up to faculty and staff, a feeling that is integral to any improvement effort designed to last, including one mandated from an outside agent. Teacher leaders, including Wagner and Crowley, were eager for a new direction. The arrival of the Cristo Rey program to their school made change possible. Medina, who kept his distance and avoided long dialogues with faculty who 
were skeptical of the changes being made, had a style that was well received by those who wanted change. "Jose has a knack for making students and teachers feel they've decided to make a change that in fact he had planned long before," explained Wagner.

\section{Considerations for School Leaders Attempting a Turnaround}

The Cristo Rey Boston experience teaches several lessons to school leaders attempting a turnaround.

Critical analysis of practice. Like any successful turnaround, the leadership of Cristo Rey Boston focused on student outcomes. Leaders of a school attempting a turnaround must take a hard and honest look at what various assessment data say about teaching and learning in the school. Faculty and staff need the freedom to question what they do, ask honestly whether the school is adding value to its students, and acknowledge that changes are needed in what and how they teach.

Commitment and accountability. Everyone in the school's leadership must commit to change and understand the work it entails. Getting teachers to change what and how they teach is a daunting task that can overwhelm any well-meaning leader. The board and superintendent or president must provide the principal and faculty the support they need to initiate changes. "It took moral courage to realize we weren't delivering on our promises, face the facts honestly and openly, and commit to change," said Wagner. "This is where Jeff's and Jose's leadership is important. Without them, we would have done what many schools have done, which is hide from reality until they quietly close."

Continued innovation and risk taking. For a turnaround to work, leaders must be willing to change often in order to meet the needs of their students. An advantage to the Cristo Rey Boston turnaround was that faculty felt empowered to innovate. The principal and his teachers looked for ways to improve and to help their students learn more. They were not bound by mandates from the central office of a school district or charter management organization. They were empowered to try new ways to teach students and to modify their approach as they moved along.

Identify and engage key leaders. It is important for the school leader to identify allies in the effort to implement change and to identify early who is or who is not on board with the changes. Medina, Wagner, and Crowley worked hard, explained to teachers what change would entail, and set a standard for 
teacher performance that others could emulate. "The most successful process results in people leaving of their own free will when they discover how much work it takes to avoid implementing the new programs," explained Wagner. "Clever leaders find ways to make staying and resisting less appealing than leaving."

Establish credibility. It is critical for school leaders to establish credibility and good faith when attempting a turnaround. The most difficult part of a turnaround is balancing a clean break with the past and honoring both the past and the present. Cristo Rey Boston's faculty did not give up on the sophomores, juniors, and seniors they were teaching in 2008-09, even though their focus was on a new ninth grade curriculum. "We were committed to getting our students to the right colleges, to teaching them as well as we could," said Medina. "We didn't say we're helping the freshmen and forgetting about the rest of the student body."

"When schools fail to properly value those in front of them because the future is the greater priority, it becomes very difficult to shed the negativity and resentment that result," said Wagner. "It would have been great if our turnaround had happened when we converted, but there is also some advantage to having two stages of change (one in 2004 and the next in 2007) because we never abandoned ourselves to the future at the expense of the past."

Foster buy-in across the entire school community. Successful turnarounds must draw upon the skills and knowledge of a dedicated and engaged staff. "Buy-in is important," explained Crowley. "We all felt like we had a part in the changes. We were not making changes because we were told to."

Leverage resources. School leaders have multiple sources of resources and support when making change. Cristo Rey Boston's educators visited high-performing charter schools, asked College Board for guidance, and sought help from other successful educators. There are educators who have been successful at making changes in schools, and they are excellent resources.

The right leadership. The Cristo Rey Boston turnaround was driven by Fr. Medina and two teachers who were energized by the vision he had for the school. They believed in their students' ability to achieve at higher levels and were able to convince their colleagues to work for this vision.

\section{Conclusion}

The underlying inspiration for the turnaround of Cristo Rey Boston High School was a moral one: School leaders knew their students deserved some- 
thing better than what they were receiving in the classroom. The task was never to save a school or improve a public image or meet state standards. The turnaround happened because school leaders decided to deliver the education they joined the school to provide in the first place. Cristo Rey Boston High School's transformation can be a model for schools determined to better serve their students. Change will take moral courage, but there are educators across the country, who, if supported, can take similar steps to those taken by a group of leaders in Boston who dramatically changed their school.

\section{References}

Calkins, A., Guenther, W., Belfiore, G., \& Lash, D. (2007). Turnaround challenge: Why America's best opportunity to dramatically improve student achievement lies in our worstperforming schools. Boston, MA: Mass Insight Education \& Research Institute.

Clotfelter, C.T., Ladd, H.F., \& Vigdor, J.L. (March 2007). How and why do teacher credentials matter for student achievement. (Working Paper 2). Washington, DC: National Center for Analysis of Longitudinal Data in Education Research. Retrieved from http://www.caldercenter.org/PDF/1ooro58 Teacher Credentials.pdf.

Cristo Rey Network. (2012). Mission Effectiveness Standards. Chicago, IL: Author. Retrieved from http://www.cristoreynetwork.org/page.cfm?p=368.

Cristo Rey Network. (2008). 2008-o9 Statistical Directory. Chicago, IL: Author.

Cristo Rey Network. (20Ira). Annual Data Report: Fall 20II. Chicago, IL: Author.

Cristo Rey Network. (2omb). The Cristo Rey Network: An Historical Profile. Chicago, IL: Author.

Duke, D.L. (2008). Diagnosing school decline. Phi Delta Kappan, 89(9), pp. 667-67I.

Duke, D.L., \& Jacobson, M. (20II). Tackling the toughest turnaround: Low-performing high schools. Phi Delta Kappan, 92(5), pp. 34-38.

Elmore, R.F. (2000). Building a new structure for school leadership. American Educator, Winter 1999-2000, pp. I-9.

Elmore, R. (2004). School reform from the inside out: Policy, practices and performance. Cambridge, MA: Harvard University Press.

Ferguson, R., Hackman, S., Hanna, R., \& Ballantine, A. (June 2010). How high schools become exemplary: Ways that leadership raises achievement and narrows gaps by improving instruction in 15 public high schools. Report on the 2009 Annual Conference of the Achievement Gap Initiative at Harvard University. Retrieved from http://www.agi. harvard.edu.

Fullan, M. (2006) Turnaround leadership. San Francisco, CA: Jossey-Bass.

Gordon, R., Kane, T.J., \& Staiger, D.O. (April 2006). Identifying effective teachers using performance on the job. The Hamilton Project, Discussion Paper 2006-or. Washington, DC: The Brookings Institute.

Hargrove, L., Godin, D., \& Dodd, B. (2008). College outcomes comparisons by AP and non-AP high school experiences. College Board Research Report No. 2008-3. New York, NY: The 
College Board.

Institute for Strategic Leadership and Learning. (February 20I2). Emerging practices in rapid achievement gain schools: An analysis of 2OIO-2OII level 4 schools to identify organizational and instructional practices that accelerate students' academic achievement. Catonsville, MD: Author. Retrieved from http://www.doe.mass.edu/boe/docs/20I2-04/item2.docx.

James, J.T. (2009). A research-based approach to the president-principal model: Problems, dynamics, and high performance through administrative alignment. Catholic Education: A Journal of Inquiry and Practice (I2)3, pp. 399-422.

Jonas, M. (Winter 20II). Grade expectations, Commonwealth Magazine.

Kahlenberg, R.D. (2010). Turnaround Schools That Work: Moving Beyond Separate but Equal. New York, NY: The Century Foundation. Retrieved from http://tcf.org/events/pdfs/ ev264/turnaround.pdf.

Kanter, R.M. (2004). Confidence: How winning streaks $\mathcal{E}$ losing streaks begin $\mathcal{E}^{2}$ end. New York, NY: Three Rivers Press.

Kearney, G.R. (2008). More than a dream: The Cristo Rey story: How one school's vision is changing the world. Chicago, IL: Loyola Press.

Leithwood, K., Harris, A., \& Strauss, T. (2010). Leading school turnaround: How successful school leaders transform low performing schools. New York, NY: John Wiley \& Sons.

Massachusetts Department of Elementary and Secondary Education. (20II). School Leaders Guide to the 2 OII Accountability Reports. Author. Retrieved from http://www.doe.mass. edu/apa/ayp/2orI/schleadersguide.pdf.

Mass Insight Education and Research Institute. (August 2009a). Meeting the turnaround challenge school case study: Springfield public schools, commonwealth pilot school, Duggan Middle School, Springfield, MA. Boston, MA: Author. Retrieved from http://www. ccebos.org/Duggan_MS_CoPilot_June_2009.pdf.

Mass Insight Education \& Research Institute. (May 2009b). Meeting the turnaround challenge school case study: Mastery Charter School Organization, Pickett Charter Middle School, Philadelphia, PA. Boston, MA: Author. Retrieved from http://www.massinsight. org/publications/stg-resources/96/file/I/pubs/2010/04/20/Pickett MS Mastery Case $\underline{\text { Study.pdf. }}$

National Association of Secondary School Principals. (1996). Breaking ranks: Changing an American institution. Washington, DC: Author.

National Center for Education Statistics. (2010). Recent high school completers and their enrollment in college, by racelethnicity: 1960 through 2008. Retrieved from http://nces. ed.gov/programs/digest/dog/tables/dtog 201.asp

North Cambridge Catholic High School. (2009). Annual Report. Cambridge, MA: Author.

North Cambridge Catholic High School. (2002). Self-study and application for membership in the Cristo Rey network. Cambridge, MA: Author.

Pappano, L. (20Io). Inside school turnarounds: Urgent hopes, unfolding stories. Cambridge, MA: Harvard Education Press.

Stern, D., Wu, C., Dayton, C., \& Maul, A. (2007). Learning by doing career academies. In D. Neumark (Ed.), Improving school-to-work transitions (pp. 134-I68). New York, NY: Russell Sage Foundation. 
Stone, J.R., \& Aliaga, O. (2007). Participation in career and technical education school-towork programs in American high schools. In D. Neumark (Ed.), Improving school-towork transitions. New York, NY: Russell Sage Foundation.

Szachowicz, S. (November 2010). Transformed by literacy. Principal leadership, pp. 17-23.

U.S. Department of Education. (2009, August 26). "Obama Administration Announces Historic Opportunity to Turn around Nation's Lowest-Achieving Public Schools.” Press Release, U.S. Department of Education. Retrieved from http://www2.ed.gov/ news/pressreleases/2009/08/08262009.html

U.S. Department of Education, Office of Elementary and Secondary Education. (2006, July 2I). LEA and School Improvement, Non Regulatory Guidance. Student Achievement and Accountability Programs. Retrieved from http://www.eric.ed.gov/PDFS/ED 4934Ig.pdf. Wagner, T., Kegan, R., Laskow, L., Lemons, R.W., Garnier, J., Howell, A., Rasmussen, H.T., \& Vander Ark, T. (2005). Change leadership: A practical guide to transforming our schools. San Francisco, CA: Jossey-Bass.

Jeff Thielman has been involved with the Cristo Rey schools since 1998 and became president of Cristo Rey Boston High School in 2009. A former trial attorney who served for three-and-a-half years as a Jesuit International Volunteer in Peru in the late I980s, he served as development director of the first Cristo Rey Jesuit High School in Chicago from 1998 to 2000. In 200I, he became the executive director of the Cassin Educational Initiative Foundation, which helped finance the start-up of the Cristo Rey schools. He is cofounder of the Cristo Rey Network, the national umbrella organization of the Cristo Rey schools and oversaw the start-up of 24 Cristo Rey schools from 2001 to 2009. He has served on the board (School Committee) of his local public school district in Massachusetts since 2003. He can be reached at jthielman@cristoreyboston.org. 